\title{
Emerging horizon for bat borne viral zoonoses
}

\author{
V. Beena ${ }^{1,2}$ (1) - G. Saikumar ${ }^{2}$
}

Received: 19 March 2019/ Accepted: 15 July 2019/Published online: 26 October 2019

(C) Indian Virological Society 2019

\begin{abstract}
Bats are the only flying placental mammals that constitute the second largest order of mammals and present all around the world except in Arctic, Antarctica and a few oceanic islands. Sixty percent of emerging infectious diseases originating from animals are zoonotic and more than two-thirds of them originate in wildlife. Bats were evolved as a super-mammal for harboring many of the newly identified deadly diseases without any signs and lesions. Their unique ability to fly, particular diet, roosting behavior, long life span, ability to echolocate and critical susceptibility to pathogens make them suitable host to harbor numerous zoonotic pathogens like virus, bacteria and parasite. Many factors are responsible for the emergence of bat borne zoonoses but the most precipitating factor is human intrusions. Deforestation declined the natural habitat and forced the bats and other wild life to move out of their niche. These stressed bats, having lost foraging and behavioral pattern invade in proximity of human habitation. Either directly or indirectly they transmit the viruses to humans and animals. Development of fast detection modern techniques for viruses from the diseased and environmental samples and the lessons learned in the past helped in preventing the severity during the latest outbreaks.
\end{abstract}

V. Beena

drbeenadevs@gmail.com

G. Saikumar

saikumarivri@gmail.com

1 Present Address: CSIR-Indian Institute of Toxicology Research, Lucknow, UP 226001, India

2 ICAR-Indian Veterinary Research Institute, Bareilly, UP 243122, India
Keywords Zoonotic $\cdot$ Viruses $\cdot$ Species $\cdot$ Asia $\cdot$ Nipha

\section{Introduction}

Bats are the only flying placental mammals that present all around the world except in Arctic, Antarctica and a few oceanic islands. They are the second largest order of mammals that evolved from one of the oldest fossil, Icaronycteris, during Eocene period (50 million years ago) and diverged into 925 known species which constitute $20 \%$ of $>4800$ mammalian species [29]. Although the bats attribute advantages in the diverse ecosystem as pest controller (insectivorous bats) and pollinators (frugivorous bats); the worrisome fact is they act as natural reservoirs for a large number of emerging as well as re-emerging pathogens that other animals and humans can contract. Moreover they gained a bad reputation in classical literatures, in which bats are associated with evils- Lucifer, darkness, Dracula- blood fed vampires and as omens and in modern scientific society they were obligatorily dangerous, as evolved as a super-mammal for harboring many of the newly identified deadly diseases without any signs and lesions. Recent database on bat viruses from 69 countries worldwide comprises more than 4100 bat-associated animal viruses belonging to 23 viridae detected in 196 bat species [6]. Recently reported $43 \%$ of the emerging and reemerging pathogens included in bioterrorism list as category A, B, C were recognized in different bat species. The emergence of bat borne zoonotic viruses significantly arise a global public health impact.

Many of the emerging and reemerging viruses are formidable foes for the physicians putting them into confusion due to their mutagenic nature. Best example is the recent report of Zika virus in India, which doesn't cause any 
developmental mutagenicity in children compared to the outbreak in Brazil in 2015. In Asia and Pacific regions, bats were demonstrated as natural reservoirs for a large number of this types of emerging as well as re-emerging pathogens such as SARS, Ebola, Marburg, Nipha, Hendra, Tioman, Menangle, Australian bat lyssa virus, Rabies and many encephalitis causing viruses in humans and animals [2]. Sub Saharan Africa, where people hunt bats as bush meat is the biggest hot spot for viral spill over from bats to humans and other mammals. Southeast Asia is also been considered as another danger zone. A change in agent, host and environment is responsible for the emergence and re emergence of various diseases. From bats the pathogen get transmitted to humans via intermediate hosts like horses(hendra) and pigs(nipah) and different species of animals get infected by consumption of partially eaten fruits of bats and the chewed out materials of bats after extracting the juice. Studies suggest bats can travel a long distance (2000-3000 km) which also develops issues of introducing new disease to the place unknown earlier. Phylogenetic analysis suggests a co evolutionary relationship between viruses and the existing bats [18]. All these facts arose international scientific attention for the study on bats and bat associated viruses and it suggests that a series of events happened to precipitate the emergence of the viruses which were ancient and circulating in the bats for a long time.

Recent applications of conventional PCR/RT PCR, metagenomics and next-generation sequencing (NGS) technologies revealed the complexity of the bat virome, which may impact upon its reservoir capacity and consequently affect vector-reservoir host interactions. Several studies showed bats as an important reservoirs for a number of RNA viruses (including, lyssa, corona, paramyxo, filo and astro viruses) and DNA viruses (including, parvo, circo, herpes and adeno) [3]. Variation in the incidence and diversity of viruses in bats suggests that some species of bats are reservoir host and some others are incidental hosts [36]. The bat virome in frugivorous bats are less compared to the insectivorous bats [57]. More than 200 viruses were reported in bats wherein most are RNA viruses. Out of 60 viruses found to be associated with bats, 59 were RNA viruses due to high degree of mutations and recombination $[28,56]$. The first report of a transmission of a viral disease from bats to humans was a rabies virus (RABV) belonging to the Lyssa virus genus [5]. Rio Bravo virus was the first non rabies virus to be recognized as originating from bats in 1960s [35]. Majority of viruses identified in bats were belonging to flavi virus group including West Nile virus and Kyasanur forest disease virus [39] and the application of metagenomics helped to identify Picorna viruses in bats.

Since a large number of different types of virus were identified in bats it is better to understand the spectrum and characteristics of viruses that bats carry. It may help to prevent and control potential emerging bat-borne diseases. Further as bats are acknowledged for emerging zoonoses, identification and characterization of novel viruses from bats is needed. Unlike other animals the detailed information regarding bat anatomy, ecology, importance in ecosystem and their ability to act as reservoirs for a large number of viruses which are potentially harmful for humans and animals have to be studied. Moreover, knowledge regarding the antibody and cytokine synthesis in bats, pathogenicity and the pathology associated with infections are lagging. Some of important pathogenic RNA viruses identified in bats so far with emphasis on Nipha virus transmission and few more bat borne viruses are discussed below.

\section{Important RNA viruses identified in different bat species and outbreak reported across the globe}

\section{Rabdoviridae}

The oldest and most eloborately studied viruses in bat was the bat lyssa virus of family Rabdoviridae. Rabies virus was detected in both haematophagus and non haematophagus bats [24]. In Australia, in 1998, a new lyssa virus from pteropid bats was characterized by sequencing, electron microscopy and by mouse model study [17]. Australian bat lyssa virus produces non suppurative meningo-encephalomyelitis and negri bodies were detected in brain of some bats with lesions similar as in rabies [22]. In Western Europe, when rabies incidence was found declining among terrestrial mammals, new cases in cats were reported. Later it was discovered as European Bat Lyssa virus 1 (EBLV1) circulating among European bats got transmitted to cats [10]. The virus is also being reported in sheep, stone marten and in humans presuming cross transmission from bats to other terrestrial mammals [11]. In Straw- colored fruit bats rabies virus was injected intracerebrally and it was found to be suffered with diffuse, mild to moderate meningoencephalitis with two to three cell layer thick perivascular cuffing [45]. Earlier Rabies bat virus (RaBV) and EBLV was restricted to America and Europe respectively. But now many reports are there about the presence of lyssa viruses in bats of other countries including India. In Asia, only few reports of rabies virus isolates; one from India and in Thailand but were not confirmed by further studies. Recently in India, bats sampled from Nagaland hills were tested positive for rabies antibodies, but the epidemiology, prevalence distribution and pathogenicity is still incomplete. All these evidences of rabies virus antibodies in different places give a room for speculation for the presence of lyssa virus in free ranging bats in India. 


\section{Paramyxovidae}

India reported the first bat parainfluenza virus of paramyxoviridae from a Rousettus leschenaulti bat in 1966 [21]. Hendra, Henipa and Nipha viruses of paramyxovirus group attain recognition as the twenty-first century emerging diseases [66]. Hendra and Nipah viruses have regular spill over from pteropus bats to humans and domestic animals. The first outbreak of hendra virus was reported in 1994, in Brisbane, Australia killing 21 horses and 2 humans. In addition to the affected target species, the seropositivity was reported from flying foxes which serve as the major reservoir host of the virus [16].

Nipha virus disease is a heart breaking disaster in which more than one million pigs were culled. It's a newly emerged deadly infection characterized by fever, respiratory distress and encephalitis and was reported in 1999 from pigs and humans in the South East and South Asian region. Later a series of outbreaks were reported in various countries like Bangladesh, Malaysia, Singapore and in India at different time points [32]. Direct contacts with infected pigs were main source and a case fatality rate of $40-100 \%$ was noticed during the outbreak. The case fatality rate in 2001 outbreak in siliguri, India was found to be $68 \%$ [52]. During initial outbreak in 2001, neutralizing antibodies for Nipha virus were detected in bats present throughout peninsular Malaysia residing around the infected pig farms [63]. Nipha virus was first isolated from urine of Pteropus hypomelanus and Pteropus vampyrus [51]. Two strains of the virus were isolated from the Pteropus lylei in Cambodia and from different species of bats in Indonesia, Thailand and Philippines [50]. All these reports suggest that the henipa virus is distributed throughout the pteropid bats in the world. An encephalitis outbreak that occurred in people of Southern Phillipines in 2014 is considered mostly due to horse meat consumption and to horses the virus get transmitted by eating the fruits partly eaten by bat [7]. Therefore the bats are proved to be the global reservoir hosts for the Paramyxo viruses. Diagrammatic representation of bat transmitted Nipha viral zoonoses is depicted in Fig. 1.

In India a survey on 140 bats of 3 different species for the pathogenic Nipha, Ebola and Marburg using enzyme linked immunosorbant assay showed Nipha virus specific IgG from serum sample of a bat [59]. The amino acid and nucleotide sequences derived from pteropus showed $100 \%$ homology to the Nipha virus reported in 2001 and 2007 outbreak in India and Bangladesh. Seropositivity for Nipha virus in Pteropus giganteus in the northern region of India was tested using indirect ELISA method and recorded 95\% sensitivity and $75 \%$ specificity when compared with CNT [14]. Bats were again proved to be the source for the recent Nipha outbreak in Kerala, India [26]. During the survey on bats for Nipha virus in Malaysia in 2001, researchers isolated a novel virus and named as Tioman virus. Later Tioman virus was isolated from the bat tissue specimen (Pteropus giganteus) in the north east region of India. Yaiw et al. [60] experimentally proved that the Tioman virus capable of infecting and replicating in lymphocytes of lymphnodes, payers patches, spleen, thymic epithelioreticular cells and tonsillar tissue of pigs. Philbey et al. [40] and Wong et al. [56] separately infected pigs oronasally with Tioman virus and postulated as this could be the possible source of paramyxovirus transmission from bats to pigs.

From three species of fruit bats, three new henipa virus and two new rubula viruses were detected from Indonesia [44]. Identification and complete genome analysis of three Tuhoko viruses (The university of Hong Kong) ThkPM 1, ThkPM2 and ThkPM3 in Roseuttues leschnaulti was
Fig. 1 Diagrammatic representation of bat borne Nipha virus transmission

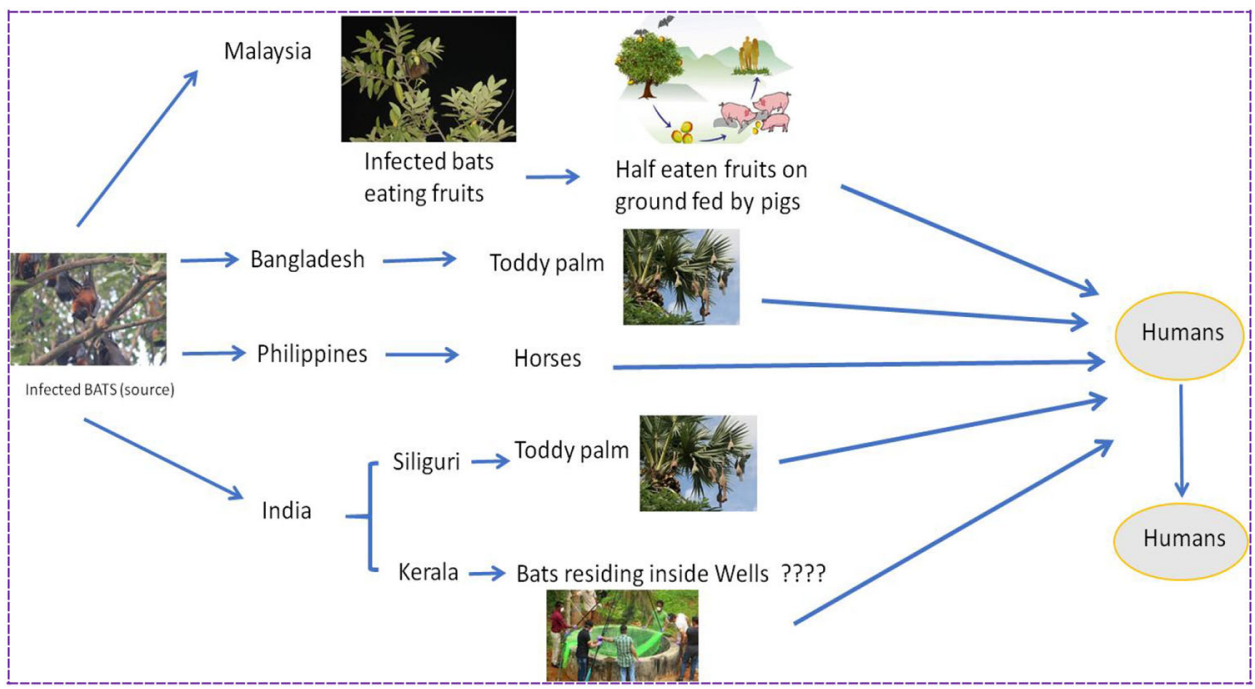


studied in China [29]. These three viruses have a common origin and in phylogenetic analysis they were found closely related to Menangle and Tioman viruses. Hendra, Nipha and Menangle virus are the only three virus of the paramyxoviridae affect humans recovered from bats so far. In China, a novel Toti virus like virus was identified and isolated from the bat guano and its cytopathic effects were studied in $\mathrm{Sf} 9, \mathrm{~Hz}$ and $\mathrm{C6} / 36$ cell lines [62]. Since these are BSL4 agents, their incidence prevalence study and pathology reports are limited in most of the Asian countries.

\section{Filo viridae}

Filo viruses are the most lethal haemorrhagic fever causing pathogen in human and non human primates. The filoviridae family includes Ebola virus (Zaire, Sudan, Reston, Tai forest and Bundybugai), Marburgh and recent Cueva virus. In Philippian, during an outbreak in 2008 Reston Ebola is found circulating in pigs and among nonsymptomatic human cases [34]. These suggest that there are multiple hosts involved in filovirus. In Bangladesh, 5 Rousettus leschenaultii bats were found seropositive against Ebola Zaire and Reston viruses [38]. In China, $R$. leschenaultii was found seropositive for Reston and Zaire ebola viruses along with other insectivorous bat species (Yuan et al. [64]). Detection of filoviruses in pigs in Philippines, fruit bats in China and Bangladesh and Orangutans from Indonesia reveal the extent of spread of the filoviruses among different species in Asia [37]. A panviral microarray study reported the presence of Reston ebolavirus co-infected with porcine reproductive and respiratory syndrome in pigs in Philippines. Towner et al. [48] using immunoperoxidase method demonstrated the peri mebranous localization of Marburg virus antigen in the liver of infected Roseuttues aegyptius bats and presence of small collections of mononuclear inflammatory cells and hepatocyte necrosis.

\section{Flaviviridae}

The epidemiological role of bats in transmission of flavi viruses is not yet clear. In Bangladesh while screening for Nipha virus a novel GB like virus was identified from sera of a single colony of Pteropus giganteus [14]. Novel GB virus $\mathrm{D}$, belongs to a new group in Flaviviridae, Pegi group. Serosurveillance of around 1650 bats from 7 different countries using unbiased high throughput sequencing method revealed the presence of sequences showing $25-100 \%$ similarity to viruses in hepaci and pegi group. This study concluded that bats are the natural reservoir for the entire hepaci and pegi groups [41]. In southern China, seroprevalance study against JE, detected the presence of antibodies in $12 \%(43 / 336)$ of bats by micro-seroneutralization test and 11 bats out of this were have neutralizing antibodies [9]. During the period from 1986 to 2009, four isolates of JE virus such as B58 from Roseuttues leschnaulti and GB30 from Murina aurata were reported in China and these isolates were similar to human Liyujie and mosquito BN19 isolates [53]. As a part of investigation on bat borne JE in Japan, a virus different to JE was accessed in serological study and named as Yokosu virus [27].

\section{Coronaviridae}

International scientific community gained interest to do research on bats after the discovery of SARS in horseshoe bats. In addition to SARS-CoV, five human coronaviruses (HCoVs), including two alpha named as -229E, -NL63, and beta corona virus like OC43, -HKU1 and a MERS CoV were identified [65]. Bats are considered as the ancestor for SARS CoV, MERS CoV, Human CoV 229E and NL63 $[13,23]$. SARS CoV like virus antibody prevalence was found to be $84 \%$ in Chinese horse shoe bats and Roseuttues sp. But pathology associated with these viruses in bats was not noticed. Large diversity of corona virus was noticed in South East Asian countries like China, Philippines, Japan and Thailand. Majority of corona viruses were discovered from tissues, blood samples and faeces, indicate an enteric tropism of this virus in bats. Detection of corona viral genome fragments in spleen and brain of Indonesian bats suggests that the virus is not restricted to the respiratory and enteric epithelium [1].

\section{Herpesviridae}

Search for the herpes viruses in bats dated back in 1996 when a Cytomegala virus particle was demonstrated in the acinar cells of submandibular gland of two Myotis lucifugus bats [47]. A novel beta herpes virus was detected from the lung, kidney, spleen, liver and blood of a number of insectivorous bats by BLAST search of the complete $\mathrm{gB}$ sequence and phylogeny base studies [55]. By targeting glycoprotein B (gB) and DNA-directed DNA polymerase (DPOL) genes of HVs, two gamma and two beta herpes virus were identified in bats in China [57]. Out of 520 faecal sample from 8 different species of bats in Southern China, 73 samples were positive for herpes virus (69 gamma herpes virus and 4 were beta herpes virus). Detection of herpes virus in the digestive tract and anal swabs of bats suggests oral faecal route as main mode of transmission for herpes virus in bats [67]. In Philippines during 2012, 70 bats belonging to megabat species were examined and a novel Gamma herpes virus was identified from $20 \%$ of the intestine (14/70) and $10 \%$ of the lung (7/ 69) and serum samples (5/52) [43]. 


\section{Important DNA viruses identified in different bat species}

\section{Adenoviridae}

Bat adenovirus was first isolated in Japan from a fruit bat (Pteropus dasymallus yayeyamae) and named as Ryukyu virus 1 -RV1 [33]. Kohl et al. [25] carried out genome pyrosequencing of bat adenovirus 2 and found there was an interspecies transmission during evolution of Canine adenovirus 1 and 2 from Vespertilionid bat adenovirus. Also, the adenovirus infected bats showed virus tropism in intestine, liver and kidneys but the lesions were noticed in spleen and lungs like follicular hyperplasia and non suppurative interstitial pneumonia respectively. Later the adenovirus was isolated during the surveillance programme for Nipha, Ebola and SARS in 2007-2008 periods in China from Myotis bats and grouped the novel Bat adeno virus TJM (Bt-Adv-TJM) in Mast adenovirus genus [31, 30]. This report also demonstrates the epidemiology of bats adenovirus is prevalent in Myotis species and Scotophilus kuhlii out of the 19 bat species surveyed in China. The fourth mastadenovirus was isolated from $R$. leschenaultii bat in India and it showed approximately $20 \%$ divergent at the nucleotide level from its closest known relative, Japanese BatAdV [42]. The average prevalence of adeno associated virus was found to be $22.4 \%$ from 5 provinces in China [31, 30]. Tan et al. [46] performed next generation sequencing for three adenovirus isolates from Rhinolophus sinicus bats in China and reported an unusually large E3 genome present in these isolates.

\section{Hepadnaviridae}

The bat hepadna can infect human hepatocyte and are antigenically related with the hepatitis B virus. Even though an effective hepatitis B vaccine is available, the virus is not globally eradicated. Recent studies suggest hepatitis $B$ virus is present in a number of free ranging bats [19]. In Asia, America and Africa during the period from 2002 to 2011, 3080 individual bats (199 liver and 2881 sera) from 54 different bat species were collected and screened using nested PCR for hepadna virus. The result shows that there was a low prevalence rate $(0.3 \%)$. Also the histological studies reveals like in all other host, only few inflammatory cells mainly lymphocytes were seen in the portal triad of the infected bats without any symptom and have high viremic form [12]. In Myanmar, out of 853 individual bats of 6 species, Bat hepatitis virus (BtHV) was detected in the pooled liver tissue of long fingered bats (Miniopterus fuliginosus) by electron microscopy and also the full genome of BtHV [19]. In china, a novel bat hepatitis virus was identified by full genome sequencing of the identified virus in Pomona roundleaf bats [20]. Recently in china out of 78 bat liver screened by RT-PCR with degenerate primers followed by sequencing and phylogentic analysis, one hepaci virus and 4 novel hepadna viruses were identified [54].

Some of the less significant viruses identified in different bat species are shown in Table 1.

\section{Concluding remarks}

Viral diseases are rising up day by day and majority are zoonotic and about $30-40 \%$ are where the bats as host. Sometimes the viruses disappear and remain passive for long time and re emerge with increased virulence. Researchers trying to develop vaccines against many viruses, but in a developing country with huge population like India, it is not advisable. For the last few decades bats are found as plethora for many numbers of viruses, but the exact role in maintenance and transmission of these viruses to terrestrial animals has not been studied yet clearly. Besides, there doesn't exist a proper pathogen database for Indian bats. By making the public aware about the major

Table 1 Bat borne viruses of less significant and frequency

\begin{tabular}{|c|c|c|c|}
\hline Virus & Host bat species & $\begin{array}{l}\text { Country } \\
\text { outbreak }\end{array}$ & References \\
\hline $\begin{array}{l}\text { Miniopterus schreibersii papilloma virus type } 1 \\
\text { (MscPV1) }\end{array}$ & Miniopterus schreibersii, Roseuttues aegyptius & China & Tse et al. [49] \\
\hline Rhinolophus ferrumequinum retrovirus (RfRV) & Myotis capaccinii, Miniopterus schreibersii & China & $\begin{array}{l}\text { Farkašová et al. } \\
\text { [15] }\end{array}$ \\
\hline Rota virus & $\begin{array}{l}\text { Eidolon helvum, Rhinolophus hipposideros, Aselliscus } \\
\text { stoliczkanus }\end{array}$ & Kenya & $\begin{array}{l}\text { He et al. [19] } \\
\text { Xia et al. [58] }\end{array}$ \\
\hline $\begin{array}{l}\text { Pulau virus, Melaka virus and Kampar virus } \\
\text { (Orthoreo virus) }\end{array}$ & Rhinolophus pusillus Hipposideros, Myotis sps & $\begin{array}{l}\text { Malaysia } \\
\text { China }\end{array}$ & $\begin{array}{l}\text { Chua et al. [8] } \\
\text { Yang et al. [61] }\end{array}$ \\
\hline
\end{tabular}


factors associated with bat borne zoonotic disease transmission such as magnitude and frequency of bat human interaction and public reminders like not to touch bats, it is easy to control and prevent the bat borne diseases to a large extent. After Ebola outbreak in West Africa, peoples in different communities were advised about the safety measures to be taken while the bush meat consumption, bat hunting and during frequent cave visits. Handling bat guano also arise health risk because in Brazil while screening of 533 fruit eating bats it was found 2 bats have high concentration of Influenza A subtype (HL18NL11) in their intestines and faeces [4]. In addition to viral zoonoses, non viral zoonotic pathogens like Histoplasma capsulatum causing histoplasmosis (fungal infection) and countless number of zoonotic bacteria were reported in bat faeces.

High prevalence and diversity of these viruses and its low pathogenicity in bats raises questions like whether virus was coevolved along with bats. Along with detection and characterization of bat born viruses, the pathology associated with these viruses in the host and the environmental factors which trigger these virus spills over will be found helpful in preventing epidemic. So as to counteract the future outbreak we have to conduct active pre emergence research such as surveillance, identification of the potent pathogens, susceptible hosts, pathogenicity on the natural hosts and the various factors triggering cross species transmission.

Deforestation and Urbanization are the major factors for all these deadly outbreaks. The human encouragement to forest areas and close contact with wild animals, increased breeding of mosquitoes in congested areas and change in climate and ecology become precipitating factors for the bat borne zoonotic viral outbreaks. All the bats borne disgusting outbreaks became a lesson for future and after the deadly viral outbreaks in different parts of the world, our country become alert to begin a fight against the viruses and it found useful in preventing a huge outbreak in recent years, Nipha and Zika outbreaks in India. Modern molecular diagnostics, the potential and biology of the agent, host immune response studies and vaccine developments helped to prevent further outbreaks to great extend. Control and management measures such as campaining the public regarding the issues, and practice personal hygiene, washing hands properly before food esp in rainy seasons and avoid eating fallen fruits and vegetables without proper washing should be followed.

\section{References}

1. Anindita PD, Sasaki M, Setiyono A, Handharyani E, Orba Y, Kobayashi S, Nakamura I. Detection of coronavirus genomes in
Moluccan naked-backed fruit bats in Indonesia. Adv Virol. 2015;160(4):1113-8.

2. Calderon A, Guzman C, Salazar-Bravo J, Figueiredo LT, Mattar S, Arrieta G. Viral zoonoses that fly with bats: a review. J Parasite Biodivers. 2016;7:1-13.

3. Calisher CH, Childs JE, Field HE, Holmes KV, Schountz T. Bats: important reservoir hosts of emerging viruses. Clin Microbiol Rev. 2006;19(3):531-45.

4. Campos ACA, Góes LGB, Moreira-Soto A, de Carvalho C, Ambar G, Sander AL, Fischer C, da Rosa AR, de Oliveira DC, Kataoka APG, Pedro WA. Bat influenza A (HL18NL11) virus in fruit bats, Brazil. Emerg Infect Dis. 2019;25(2):333.

5. Carini A. Sur une grande épizootie de rage. Ann Inst Pasteur. 1911;25:843-6.

6. Chen L, Liu B, Yang J, Jin Q. DBatVir: the database of batassociated viruses. Database, 2014.

7. Ching PKG, de los Reyes VC, Sucaldito MN, Tayag E, ColumnaVingno AB, Malbas FF, Dueger E. Outbreak of henipavirus infection, Philippines, 2014. Emerg Infect Dis. 2015;21(2):328.

8. Chua KB, Crameri G, Hyatt A, Yu M, Tompang MR, Rosli J, McEachern J, Crameri S, Kumarasamy V, Eaton BT, Wang LF. A previously unknown reovirus of bat origin is associated with an acute respiratory disease in humans. Proc Natl Acad Sci. 2008;104(27):11424-9.

9. Cui J, Holmes EC. Endogenous hepadnaviruses in the genome of the budgerigar (Melopsittacus undulatus) and the evolution of avian hepadnaviruses. J Virol. 2012;86(14):7688-91.

10. Dacheux L, Larrous F, Mailles A, Boisseleau D, Delmas O, Biron C, Lefranc T. European bat lyssavirus transmission among cats, Europe. Emerg Infect Dis. 2009;15(2):280.

11. Davis PL, Holmes EC, Larrous F, Van der Poel WH, Tjørnehøj K, Alonso WJ, Bourhy H. Phylogeography, population dynamics, and molecular evolution of European bat lyssaviruses. J Virol. 2005;79(16):10487-97.

12. Drexler JF, Geipel A, König A, Corman VM, van Riel D, Leijten LM, Schlegel M. Bats carry pathogenic hepadnaviruses antigenically related to hepatitis B virus and capable of infecting human hepatocytes. Proc Natl Acad Sci. 2013;110(40):16151-6.

13. Drexler JF, Gloza-Rausch F, Glende J, Corman VM, Muth D, Goettsche M, Zhelyazkov L. Genomic characterization of severe acute respiratory syndrome-related coronavirus in European bats and classification of coronaviruses based on partial RNA-dependent RNA polymerase gene sequences. J Virol. 2010;84(21):11336-49.

14. Epstein JH, Prakash V, Smith CS, Daszak P, McLaughlin AB, Meehan G, Cunningham AA. Henipavirus infection in fruit bats (Pteropus giganteus), India. Emerg Infect Dis. 2008;14(8):1309.

15. Farkašová $H$, Hron $T$, Pačes $J$, Hulva $P$, Benda $P$, Gifford RJ, Elleder D. Discovery of an endogenous Deltaretrovirus in the genome of long-fingered bats (Chiroptera: Miniopteridae). Proc Natl Acad Sci. 2017;114(12):3145-50.

16. Goldspink LK, Edson DW, Vidgen ME, Bingham J, Field HE, Smith CS. Natural Hendra virus infection in flying-foxes-tissue tropism and risk factors. PLoS ONE. 2015;10(6):e0128835.

17. Gould AR, Hyatt AD, Lunt R, Kattenbelt JA, Hengstberger S, Blacksell SD. Characterisation of a novel lyssavirus isolated from Pteropid bats in Australia. Virus Res. 1998;54(2):165-87.

18. Guo WP, Lin XD, Wang W, Tian JH, Cong ML, Zhang HL, Xu J. Phylogeny and origins of hantaviruses harbored by bats, insectivores, and rodents. PLoS Pathog. 2013;9(2):e1003159.

19. He B, Fan Q, Yang F, Hu T, Qiu W, Feng Y, Li Z, Li Y, Zhang F, Guo H, Zou X. Hepatitis virus in long-fingered bats, Myanmar. Emerg Infect Dis. 2013;19(4):638.

20. He B, Zhang F, Xia L, Hu T, Chen G, Qiu W, Fan Q, Feng Y, Guo H, Tu C. Identification of a novel Orthohepadnavirus in pomona roundleaf bats in China. Adv Virol. 2015;160(1):335-7. 
21. Hollinger BF, Pavri KM. Bat parainfluenza virus. Immunological, chemical and physical properties. Am J Trop Med Hyg. 1971;20(1):131-8.

22. Hooper PT, Fraser GC, Foster RA, Storie GJ. Histopathology and immunohistochemistry of bats infected by Australian bat lyssavirus. Aust Vet J. 1999;77(9):595-9.

23. Ithete NL, Stoffberg S, Corman VM, Cottontail VM, Richards LR, Schoeman MC, Preiser W. Close relative of human middle east respiratory syndrome coronavirus in bat, South Africa. Emerg Infect Dis. 2013;19(10):1697.

24. Johnson N, Aréchiga-Ceballos N, Aguilar-Setien A. Vampire bat rabies: ecology, epidemiology and control. Viruses. 2014;6(5):1911-28.

25. Kohl C, Vidovszky MZ, Mühldorfer K, Dabrowski PW, Radonić A, Nitsche A, Harrach B. Genome analysis of bat adenovirus 2: indications of interspecies transmission. $\mathrm{J}$ Virol. 2012;86(3):1888-92.

26. Kumar AA, Kumar AA. Deadly Nipah outbreak in Kerala: lessons learned for the future. Indian J Crit Care Med Peer-Rev Off Publ Indian Soc Crit Care Med. 2018;22(7):475.

27. Kuno G, Chang GJJ, Tsuchiya KR, Karabatsos N, Cropp CB. Phylogeny of the genus Flavivirus. J Virol. 1998;72(1):73-83.

28. Lau SK, Woo PC, Li KS, Huang Y, Tsoi HW, Wong BH, Yuen $\mathrm{KY}$. Severe acute respiratory syndrome coronavirus-like virus in Chinese horseshoe bats. Proc Natl Acad Sci. 2005;102(39):14040-5.

29. Lau SK, Woo PC, Wong BH, Wong AY, Tsoi HW, Wang M, Li KS. Identification and complete genome analysis of three novel paramyxoviruses, Tuhoko virus 1,2 and 3 , in fruit bats from China. Virology. 2010;404(1):106-16.

30. Li Y, Ge X, Hon CC, Zhang H, Zhou P, Zhang Y, Shi Z. Prevalence and genetic diversity of adeno-associated viruses in bats from China. J Gen Virol. 2010;91(10):2601-9.

31. Li L, Victoria JG, Wang C, Jones M, Fellers GM, Kunz TH, Delwart E. Bat guano virome: predominance of dietary viruses from insects and plants plus novel mammalian viruses. J Virol. 2010;84(14):6955-65.

32. Lo Presti A, Cella E, Giovanetti M, Lai A, Angeletti S, Zehender G, Ciccozzi M. Origin and evolution of Nipah virus. J Med Virol. 2016;88(3):380-8.

33. Maeda K, Hondo E, Terakawa J, Kiso Y, Nakaichi N, Endoh D, Mizutani T. Isolation of novel adenovirus from fruit bat (Pteropus dasymallus yayeyamae). Emerg Infect Dis. 2008;14(2):347.

34. Marsh GA, Haining J, Robinson R, Foord A, Yamada M, Barr JA, Rollin PE. Ebola Reston virus infection of pigs: clinical significance and transmission potential. $J$ Infect Dis. 2011;204(supp1_3):S804-9.

35. Moratelli R, Calisher $\mathrm{CH}$. Bats and zoonotic viruses: can we confidently link bats with emerging deadly viruses? Mem Inst Oswaldo Cruz. 2015;110(1):1-22.

36. Mortlock M, Kuzmin IV, Weyer J, Gilbert AT, Agwanda B, Rupprecht CE, Markotter W. Novel paramyxoviruses in bats from sub-Saharan Africa, 2007-2012. Emerg Infect Dis. 2015;21(10):1840.

37. Olival K, Hayman D. Filoviruses in bats: current knowledge and future directions. Viruses. 2014;6(4):1759-88.

38. Olival KJ, Islam A, Yu M, Anthony SJ, Epstein JH, Khan SA, Luby SP. Ebola virus antibodies in fruit bats, Bangladesh. Emerg Infect Dis. 2013;19(2):270.

39. Pavri KM, Singh KR. Kysanuar forest disease virus infection in the frugiviorous bats, Cynopterus sphinx. Indian J Med Res. 1968;56(8):1202-4.

40. Philbey AW, Kirkland PD, Ross AD, Davis RJ, Gleeson AB, Love RJ, Hyatt AD. An apparently new virus (family Paramyxoviridae) infectious for pigs, humans, and fruit bats. Emerg Infect Dis. 1998;4(2):269.
41. Quan PL, Firth C, Conte JM, Williams SH, Zambrana-Torrelio $\mathrm{CM}$, Anthony SJ, Osinubi MO. Bats are a major natural reservoir for hepaciviruses and pegiviruses. Proc Natl Acad Sci. 2013;110(20):8194-9.

42. Raut CG, Yadav PD, Towner JS, Amman BR, Erickson BR, Cannon DL, Mourya DT. Isolation of a novel adenovirus from Rousettus leschenaultii bats from India. Intervirology. 2012;55(6):488-90.

43. Sano K, Okazaki S, Taniguchi S, Masangkay JS, Puentespina R, Eres E, Hatta Y. Detection of a novel herpesvirus from bats in the Philippines. Virus Genes. 2015;51(1):136-9.

44. Sasaki M, Setiyono A, Handharyani E, Rahmadani I, Taha S, Adiani S, Kimura T. Molecular detection of a novel paramyxovirus in fruit bats from Indonesia. Virol J. 2012;9(1):240.

45. Suu Ire R, Fooks A, Banyard A, Seldon D, Amphonsah-Manesha $\mathrm{K}$, Rielsa S, Cunningham A. Lagos bat virus infection dynamics in free ranging straw coloured fruit bats (Eidolon Helvum). Trop Med Infect Dis. 2017;2(3):25.

46. Tan B, Yang XL, Ge XY, Peng C, Zhang YZ, Zhang LB, Shi ZL. Novel bat adenoviruses with an extremely large E3 gene. J Gen Virol. 2016;97(7):1625-35.

47. Tandler B. Cytomegalovirus in the principal submandibular gland of the little brown bat, Myotis lucifugus. J Comp Pathol. 1996;114(1):1-9.

48. Towner JS, Amman BR, Sealy TK, Carroll SAR, Comer JA, Kemp A, Formenty PB. Isolation of genetically diverse Marburg viruses from Egyptian fruit bats. PLoS Pathog. 2009;5(7):e1000536.

49. Tse H, Tsang AK, Tsoi HW, Leung AS, Ho CC, Lau SK, Yuen KY. Identification of a novel bat papillomavirus by metagenomics. PLoS ONE. 2012;7(8):e43986.

50. Wacharapluesadee S, Hemachudha T. Duplex nested RT-PCR for detection of Nipah virus RNA from urine specimens of bats. J Virol Methods. 2007;141(1):97-101.

51. Wacharapluesadee S, Samseeneam P, Phermpool M, Kaewpom T, Rodpan A, Maneeorn P, Srongmongkol P, Kanchanasaka B, Hemachudha T. Molecular characterization of Nipah virus from Pteropus hypomelanus in Southern Thailand. Virol J. 2016;13(1):53.

52. Wahed F, Kader SA, Nessa A, Mahamud MM. Nipah virus: an emergent deadly Paramyxovirus infection in Bangladesh. J Bangladesh Soc Physiol. 2011;6(2):134-9.

53. Wang JL, Pan XL, Zhang HL, Fu SH, Wang HY, Tang Q, Liang GD. Japanese encephalitis viruses from bats in Yunnan, China. Emerg Infect Dis. 2009;15(6):939.

54. Wang B, Yang XL, Li W, Zhu Y, Ge XY, Zhang LB, Zhang YZ, Bock CT, Shi ZL. Detection and genome characterization of four novel bat hepadnaviruses and a hepevirus in China. Virol J. 2017;14(1):40.

55. Watanabe S, Masangkay JS, Nagata N, Morikawa S, Mizutani T, Fukushi S, Taniguchi S. Bat coronaviruses and experimental infection of bats, the Philippines. Emerg Infect Dis. 2010;16(8):1217.

56. Wong KT, Shieh WJ, Kumar S, Norain K, Abdullah W, Guarner J, Goh KJ. Nipah virus infection: pathology and pathogenesis of an emerging paramyxoviral zoonosis. Am J Pathol. 2002;161(6):2153-67.

57. Wu Z, Ren X, Yang L, Hu Y, Yang J, He G, Liu L. Virome analysis for identification of novel mammalian viruses in bat species from Chinese provinces. J Virol. 2012;86(20):10999-1012.

58. Xia L, Fan Q, He B, Xu L, Zhang F, Hu T, Wang Y, Li N, Qiu W, Zheng Y, Matthijnssens J, Tu C. The complete genome sequence of a G3P[10] Chinese bat rotavirus suggests multiple bat rotavirus inter-host species transmission events. Infect Genet Evol. 2014;28:1-4. 
59. Yadav PD, Raut CG, Shete AM, Mishra AC, Towner JS, Nichol ST, Mourya DT. Detection of Nipah virus RNA in fruit bat (Pteropus giganteus) from India. Am J Trop Med Hyg. 2012;87(3):576-8.

60. Yaiw KC, Bingham J, Crameri G, Mungall B, Hyatt A, Yu M, Wong KT. Tioman virus, a paramyxovirus of bat origin, causes mild disease in pigs and has a predilection for lymphoid tissues. J Virol. 2008;82(1):565-8.

61. Yang XL, Hu B, Wang B, Wang MN, Zhang Q, Zhang W, Wang LF. Isolation and characterisation of novel bat corona virus closely related to the direct progenitor of severe acute respiratory syndromecorona virus. J Virol. 2016;90(6):3253-6.

62. Yang X, Zhang Y, Ge X, Yuan J, Shi Z. A novel totivirus-like virus isolated from bat guano. Adv Virol. 2012;157(6):1093-9.

63. Yob JM, Field H, Rashdi AM, Morrissy C, van der Heide B, Rota $\mathrm{P}$, Ksiazek T. Nipah virus infection in bats (order Chiroptera) in peninsular Malaysia. Emerg Infect Dis. 2001;7(3):439.

64. Yuan JF, Zhang YJ, Li JL, Zhang YZ, Wang LF, Shi ZL. Serological evidence of ebolavirus infection in bats, China. Virol J. 2012;9:236. https://doi.org/10.1186/1743-422X-9-236.
65. Zaki AM, Van Boheemen S, Bestebroer TM, Osterhaus AD, Fouchier RA. Isolation of a novel coronavirus from a man with pneumonia in Saudi Arabia. N Engl J Med. 2012;367(19):1814-20.

66. Zeltina A, Bowden TA, Lee B. Emerging paramyxoviruses: receptor tropism and zoonotic potential. PLoS Pathog. 2016;12(2):e1005390.

67. Zheng XY, Qiu M, Chen SW, Xiao JP, Ma LZ, Liu S, Zhou JH, Zhang QH, Li X, Chen Z, Wu Y, Chen HF, Jiang LN, Xiong YQ, Ma SJ, Zhong XS, Huo ST, Ge J, Cen SW, Chen Q. High prevalence and diversity of viruses of the subfamily Gammaherpesvirinae, family Herpesviridae, in fecal specimens from bats of different species in southern China. Arch Virol. 2016;161(1):135-40.

Publisher's Note Springer Nature remains neutral with regard to jurisdictional claims in published maps and institutional affiliations. 